\title{
Corporate Shareholding Structure and Dividend Payout Ratio of Listed Chemical and Paints Companies in Nigeria
}

\author{
Kabiru Isa Dandago $\mathrm{PhD}^{1}$, Musa Adeiza Farouk ${ }^{2}$ Latifat Muhibudeen ${ }^{3}$ \\ ${ }^{1}$ Department of Accounting, Bayero University, Kano, Nigeria. \\ ${ }^{2}$ Department of Accounting, Kaduna State University, Kaduna, Nigeria. \\ ${ }^{3}$ Department of Accounting and Finance, Northwest University, Kano, Nigeria. \\ Correspondence: Musa Adeiza Farouk, Department of Accounting, Kaduna State University, Kaduna - Nigeria., P.M.B. \\ 2339.
}

Received: March 24, 2015

Accepted: April 10, 2015

Available online: April 22, 2015

doi:10.11114/afa.v1i2.789

URL: http://dx.doi.org/10.11114/afa.v1i2.789

\begin{abstract}
This paper is an empirical analysis of influence of Corporate Shareholdings Structure on Dividend payout ratio of listed Chemical and Paints Companies in Nigeria. The study is for the period of 2008-2013. The listed Chemical and Paints Companies are Eight (8) in number as provided by Nigerian stock exchange factbook for 2013. All the eight firms were used for the study. Corporate Shareholdings Structure was proxy with managerial shareholding, institutional shareholding, block shareholding and foreign shareholdings, while dividend payout ratio was proxy with dividends to net income for the same period. The data were collected from secondary source through the annual reports and accounts of the firm. The study adopted multiple regression technique. The findings revealed that managerial shareholdings has negatively, strongly and significantly impacted on dividend payout ratio of listed Chemical and Paints Companies in Nigeria, while Institutional shareholdings, Foreign shareholdings have positive, strong and significant influence on dividend payout ratio. But block shareholding shows no significant contribution to dividend payout ratio. It is recommended amongst others that the listed Chemical and Paints Companies should increase the number of shares allotted to institutional shareholders and foreign shareholders where investors are only interested in dividend payment as it may serve as a sure means of having increase in payment of dividend to shareholders. But where shareholders are only interested in capital gain rather than dividend payment, the shares held by management should be increased as this will discourage payment of high dividend in favour of capital gain.
\end{abstract}

Keywords: Dividend payout ratio, corporate shareholdings structure, Bird-in-hand theory, Signaling theory, Agency theory.

\section{Introduction}

Dividend is one of the rewards to the shareholder for their contribution in raising fund for a company and for bearing the relevant risks. In this regard, management of a company formulates a dividend policy to divide and distribute earnings among the shareholders for their investments. Dividend policies have crucial influence on the value of firm. This is because a company has to maintain a state of equilibrium between the firm's growth policies and the dividend payout policies. A minor mistake can lead to shareholders dissatisfaction as well as can shake the firm's growth.

Due to the extent of business relationships which led to agency relationships, investors are sceptical that managers may take decisions for their self interest. So, the need for corporate governance is the necessity to restore investors' confidence in business operations through transparency, accountability and responsibility. Corporate governance includes a set of relationships between a company's management, board, shareholders and other interested parties which will determine the direction of companies' movement.

One of the main features of corporate governance system are the shareholders. They indirectly play a role in corporate decision-making especially when it comes to issues regarding dividend payment and capital gain and can be effective in reducing agency costs. So, in a good corporate governance system, directors are accountable to the board and the board is accountable to shareholders and other interested parties (Esmailzadeh, Jalili, \& Zand, 2010).

Since shareholders are aware that interests of executives are not consistent with them, they also use other mechanism 
for controlling managers. One of these mechanisms is paying a lot of attention to the structure of ownership. Therefore, some are of the opinion that one way to reduce the cost of conflict of interests between managers and owners is through increase in dividend payment as this may inform the owners that they (directors) are moving in line with corporate goals and shareholders also gain more confidence about performance of the directors. Thus, the dividend is a factor to reduce the cost of conflicts of interest and as such dividend payment or its increase will satisfy the interest of the shareholders (Mashayekh \& Abdollahi, 2011). While some are of the view that investors may only be interested in capital gain rather than payment of dividend. Corporate governance is a mechanism and means of creating balance between shareholders and management in order to reduce agency problems, which will in-turn reduce the probability that managers pursue suboptimal dividend policy (Fakhari \& Yosofalitabar, 2010).

Given to the above background, it could be said that there has not been unanimous agreement by researchers on this subject matter due to the inconclusive nature of their researches and their mixed findings. The main objective of this study, therefore, is to investigate whether the structure of shareholdings have effect on the dividend policy of listed Chemical and Paints companies in Nigeria? The specific objectives are set out below:

\subsection{Objectives of the Study}

The major objective of the study is to ascertain the level to which corporate shareholdings structure influences the dividend payout ratio of listed Chemical and Paints Companies in Nigeria. Therefore the following specific objectives are set out below:

i. to examine the impact of managerial shareholdings (MSH) on dividend payout ratio of Listed Chemical and Paints Companies in Nigeria;

ii. to investigate the influence of institutional shareholdings (ISH) on dividend payout ratio of Listed Chemical and Paints Companies in Nigeria;

iii. to determine the effect of block shareholdings (BSH) on dividend payout ratio of Listed Chemical and Paints Companies in Nigeria;

iv. to determine the contribution of foreign shareholdings (FSH) on dividend payout ratio of Listed Chemical and Paints Companies in Nigeria;

In line with the above stated objectives, the study hypothesized the following hypotheses in null form.

Ho1. Managerial shareholdings have no significant impact on dividend payout ratio

Ho2. Institutional shareholdings have no significant influence on dividend payout ratio

Ho3: Block shareholdings have no significant effect on dividend payout ratio

Ho4: Foreign shareholdings have no significant effect on dividend payout ratio

A study of this nature will no doubt serve as an indispensable planning tool for managers, policy makers, Investors and potential investors. It will assist managers to see corporate shareholdings structure that helps in maximizing shareholders wealth through the payment of dividend or capital gain.

In order to achieve the above stated objectives, this paper is organized into five sections, with this section being the Introduction. Section 2 deals with the review of relevant and related literatures. Section 3 is dedicated to the methodology of the study. Section 4 and 5 present and discusses the results of the data analysis after which conclusions were made.

\section{Literature Review and Theoretical Framework}

\subsection{Managerial shareholdings and Dividend Payout Ratio}

Jensen (1986) argued that managers prefer to retain earning instead of giving it to shareholders as a dividend. Managers want to use the resources for the growth of the firm as well as for their personal benefits. Eckbo and Verma, (1994) showed that dividend decreases with the increasing power of managerial ownership and also argued that in the managers' controlled firms where they have absolute voting power, the cash dividend is zero. The analysis of Chen, Cheung, Stouraitis and Wong (2005) also showed a negative relationship between the managerial ownership and dividend policy. Short, Zhang and Keasey (2002) found that there is a negative relationship between managerial ownership and dividend payout policy. Wen and Jia (2010) found that managerial ownership is negatively associated with dividend policy in the bank holding companies. Jensen, Donald and Thomas (1992) argued that the managerial ownership has a negative impact on the dividend payout policy and the firm's debt. Mehrani, Moradi and Eskandar (2011) found the evidence in support of negative association between the managerial ownership and dividend payment policy. The relationship is also clearly recognized in the work of Short, Hao and Kevin (2002) who found a negative alliance between managerial ownership and dividend policy. Gugler and Yurtoglu (2003) find a large negative effect of 
announced dividend changes in German companies where corporate insiders have more power.

\subsection{Institutional Shareholdings and Dividend Payout Ratio}

Institutional investors are the large investors such as banks, investments firms, insurance companies and other financial institutions etc, who having huge sum of money are capable of investing money in different corporations. Therefore, they are very influential in performing their corporate governance roles. Corporate governance is specifically geared towards reduction of agency cost. Many prior studies such as Waud (1966), Fama and Babiak (1968) and Short et al. (2002) suggested that there is significant relationship between the dividend policy and institutional ownership. Wen and Jia (2010) found that Institutional ownership is negatively associated with dividend policy in bank holding companies. The relationship is also clearly recognized in the work of Short et al. (2002) who found a positive alliance between institutional ownership and dividend policy. Many theories are considered important for the relationship between institutional ownership and dividend policy which among others are agency theory and signaling theory.

\subsection{Block Shareholdings and Dividend Payout Ratio}

Concentrated ownership refers to the structure where large shareholders own the huge amount of a firm stock. These concentrated ownership or block-holders (the investors who hold at least $5 \%$ or more of the firm stock) are more concerned about the monitoring of the management decisions with the purpose of protecting their investments. Concentrated ownership plays a significant role in corporate policies, especially concerning the dividend payment policy. The management will also give preference to the large shareholders because of their influential impact on the firm's important decisions. Kouki and Guizani (2009) stressed that Tunisian companies having concentrated ownership distribute more dividends. The study also shows positive relationship between concentrated ownership and dividend payout. According to Mitton (2005), there exist the positive association between block holding and dividend Payout in emerging market. Ramli (2010) empirically found in the study of Malaysian listed companies, where ownership structure is more concentrated, that as the shares of the large shareholders increases, firms will strive to make higher dividend payout because controlling shareholders have greater influence over the dividend payout policy. Some prior studies also showed negative relationship between the concentrated ownership and dividend policy. Gugler and Yutoglu (2003) showed that firms with high ownership concentration tend to pay lower dividends. Maury and Pajuste (2002) argued that the existence of concentrated large shareholder negatively affects the dividend payout and they found the negative relation between the ownership concentration of control and the dividend payout. All these prior studies have observed that firm's concentrated shareholders can influence the dividend policy.

\subsection{Foreign Shareholdings and Dividend Payout Ratio}

Kang and Stulz (1997) find that foreigners investing in Japan tend to underweight smaller and highly leveraged firms. They argue that foreigners invest in firms that they are better informed about to reduce the costs associated with informational asymmetries. As Kang and Stulz, Dahlquist and Robertsson (2001) find foreign owners of Swedish firms show a preference for large firms, firms paying low dividends, and firms with large cash positions on their balance sheets. Rozeff, 1982; Easterbrook, 1984 found that the level of foreign ownership is positively associated with dividend payouts.

\subsection{Theoretical Framework}

\subsubsection{Agency Theory}

Even if a firm does not have free cash flow, dividend payments can still be useful for the shareholders in order to control the overinvestment problem. Easterbrook (1984) argues that dividends reduce the overinvestment problem because the payment of dividends increases the frequency with which firms have to go to equity markets in order to raise additional capital. In the process of attracting new equity, firms subject themselves to the monitoring and disciplining of these markets. This lowers agency cost. For the purpose of this research work, the above theory is used to underpin the study.

\section{Methodology and Model Specification}

This study adopts the Ex-post factor design method. This is because the study investigates the impact of corporate shareholdings structure on dividend payout ratio of listed Chemical and Paints Companies in Nigeria. The data for this study were obtained mainly from secondary sources which were collected from the audited annual reports and accounts of the listed Chemical and Paints Companies in Nigeria. The population of the study consists of the Eight (8) listed Chemical and Paints Companies in Nigeria. The data of the eight firms were used. This used the Ordinary Least Square Multiple regression technique. Multiple regression technique was used and SPSS was used as our tool of analysis.

\subsection{Model Specification}

In an attempt to examine the influence of corporate shareholdings structure on dividend payout ratio of listed Chemical and Paints Companies in Nigeria, a multiple linear model is built. The model captures the contribution of Managerial 
shareholdings, Institutional shareholdings, Block shareholdings, and foreign shareholdings on dividend payout ratio of listed Chemical and Paints Companies in Nigeria.

$$
\text { DIVPAYit }=\alpha+\beta 1 \text { MSHit }+\beta 2 \text { ISHit }+\beta 3 \text { BSHit }+\beta 4 \text { FSHit }+\beta 5 \text { ROAit }+\beta 6 \text { GRWTHit }+\beta 7 \text { LEVit }+\mu \text { it }
$$

Where DIVPAY is Dividend Payout ratio measured as dividends to net income for the same period

MSH: Managerial shareholdings measured as the ratio of shares held by the management to total shares in issues

ISH: Institutional shareholdings measured as the ratio of shares held by institutions to total shares in issues

BSH: Block shareholdings measured as the ratio of shares held in block to total shares in issues

FSH: Foreign shareholdings measured as the ratio of shares held by foreigners to total shares in issues

ROA: Return on assets measured as the ratio of profit after tax to total assets

GRWTH: Growth measured as the changes in total assets

LEV: Leverage measured as the ratio of total debt to total assets

$\alpha$ is constant

$\beta 1-\beta 7$ are the coefficient of the parameter estimate.

$\mu$ is the error term.

\section{Results and Conclusions}

This segment presents the analysis of the data and tests of hypotheses formulated in section one of the paper. First, descriptive statistics table is presented and analysed, followed by the correlation matrix table and the summary of Regression Result table, The policy implications and Recommendation are made and drawn from the findings of the study.

\subsection{Descriptive Statistics}

Table 4.1 Descriptive Statistics

\begin{tabular}{llllll}
\hline Variable & Min & Max & Mean & Std. Dev. & Skewness \\
\hline DIVPAY & .0000 & .9786 & .087685 & .2092192 & 2.899 \\
MSH & .01 & .65 & .2390 & .22041 & .559 \\
ISH & .00 & .78 & .4350 & .20197 & -.706 \\
BSH & .16 & .96 & .6992 & .20088 & -.971 \\
FSH & .00 & .39 & .0300 & .10068 & 3.128 \\
ROA & -2.76 & 5.92 & 0.0660 & 1.07217 & 2.983 \\
GRWTH & -55.83 & 58.17 & 4.2248 & 13.59596 & -0.097 \\
LEV & 0.13 & 0.97 & 0.5681 & 0.24166 & 0.047 \\
\hline
\end{tabular}

Author's Computation, 2014

From Table 4.1 above, the mean value for dividend payout ratio is $9 \%$ for firms, while Managerial shareholdings and Institutional shareholdings were having an average value of $24 \%$ and $44 \%$ respectively. Also, Block shareholdings have an average value of about $70 \%$ and foreign shareholdings mean value stood at 3\% within the period of the study. The minimum value for dividend payout ratio is 0.000 while the maximum is 0.9786 . The minimum value of dividend payout ratio is as a result of the fact that some of the firms do not pay dividend for some years. Managerial shareholdings have a minimum value of 0.01 and a maximum value of 0.65 . Institutional and foreign shareholdings recorded a minimum value zero ( 0 ) and a maximum value of 0.78 and 0.39 respectively. Block shareholdings recorded a minimum value of 0.16 and a maximum value of 0.96 . It is observed that among the independent variables, managerial shareholdings have the highest standard deviation and therefore it shows that the managerial shareholdings have the least contribution to the endogenous variable. While on the other hand, foreign shareholdings have the lowest standard deviation and it therefore shows its highest contribution to the regressand of the study. The skewness values were all close to 0 and 1 which implies that the data is tolerably mild and normally distributed except for dividend payout ratio and foreign shareholdings that is high than normal. Therefore the result from the normality test substantiates the validity of the regression result.

\subsection{Correlation Matrix}

The table below explains the association between the regressand and the regressors and also the association between the regressors themselves. The values were extracted from the Pearson correlation of two-tailed significance. 
Table 4.2 Correlation Matrix

\begin{tabular}{lllllllll}
\hline Variable & DIVPAY & MSH & ISH & BSH & FSH & ROA & GRWTH & LEV \\
\hline DIVPAY & 1 & & & & & & & \\
MSH & $-0.379 *$ & 1 & & & & & & \\
ISH & 0.108 & 0.094 & 1 & & & & & \\
BSH & $-0.254^{*}$ & $0.688^{*}$ & $-0.367^{*}$ & 1 & & & & \\
& $*$ & & $*$ & & & & & \\
FSH & -0.084 & $0.521^{*}$ & -0.112 & $0.395^{*}$ & 1 & & & \\
ROA & 0.155 & -0.147 & -0.209 & 0.038 & 0.038 & 1 & & \\
GRWTH & 0.111 & 0.148 & 0.195 & -0.042 & -0.04 & -0.837 & 1 & \\
& & & & & 2 & $*$ & & \\
LEV & -0.102 & $-0.417^{*}$ & -0.261 & 0.077 & 0.077 & 0.102 & -2.237 & 1 \\
& & $*$ & & & & & & \\
\hline
\end{tabular}

Author's Computation, 2014

*. Correlation is significant at the 0.01 level (2-tailed).

**. Correlation is significant at the 0.05 level (2-tailed).

***. Correlation is significant at the 0.10 level (2-tailed).

Table 4.2 above shows that all the independent variables (MSH, BSH and FSH) are negatively related with DIVPAY except ISH that is positively associated with DIVPAY. However, managerial shareholding is significantly related with Dividend payout ratio at $1 \%$ level of significance indicating a strong, negative relationship. Also Block shareholding is strongly, negatively and significantly related to dividend payout ratio at $10 \%$ level of significance. While for Institutional shareholdings, foreign shareholdings and Dividend payout ratio were insignificantly related. Amongst the exogenous variables, the relationship was very weak as expected except for only few of the independent variables that were significantly related. While some of the independent variables are negatively related, some were also positively related with themselves. The tolerance values and the variance inflation factor are two good measures of assessing multicolinearity between the independent variables in a study. The result shows that variance inflation factor were consistently smaller than ten (10) indicating complete absence of multicolinearity (Neter et 'al; 1996 and Cassey et 'al; 1999 as cited in Shehu \& Buba, 2011). This shows the suitability of the study model been fit with the four independent variables. Also, the tolerance values were consistently smaller than 1.00 , therefore extend the fact that there is complete absence of multicolinearity between the independent variables (Tobachmel \& Fidell, 1996).

The Summary of regression result is presented in Table 4.3

This table shows the regression result of the endogenous variable (DIVPAY) and the exogenous variables of the study (MSH, ISH, BSH and FSH). The presentation is followed by the analysis of the relationship and contribution of all the independent variables to the dependent variable of the study and also the cumulative analysis.

Table 4.3 Summary of Regression Result

\begin{tabular}{llllll}
\hline Variable & Coefficient & t-values & P-values & Tolerance & VIF \\
\hline Constant & .319 & 2.442 & 0.019 & & \\
MSH & -.580 & -3.162 & 0.003 & 0.335 & 2.981 \\
ISH & .295 & 2.137 & 0.039 & 0.705 & 1.419 \\
BSH & -.185 & -1.004 & 0.321 & 0.400 & 2.503 \\
FSH & .756 & 2.465 & 0.018 & 0.574 & 1.741 \\
ROA & .140 & 3.371 & 0.002 & 0.277 & 3.612 \\
GRWTH & .011 & 3.182 & 0.003 & 0.271 & 3.687 \\
LEV & -.295 & -2.429 & 0.020 & 0.636 & 1.571 \\
R & & & & & 0.706 \\
R2 & & & & & 0.499 \\
Adj R2 & & & & & 0.411 \\
F-Stat. & & & & & 5.690 \\
F-Sig & & & & & 0.000 \\
D/W & & & & & 1.295 \\
\hline
\end{tabular}

Author's Computation, 2014

DIVPAY $=0.319-0.580($ MSHit $)+0.295$ (ISHit) -0.185 (BSHit $)+0.756($ FSHit $)+0.140($ ROAit $)+0.011($ GRWTHit $)-$ 0.295 (LEVit) + 0.1605332 
The cumulative correlation between the endogenous variable and all the exogenous variables is 0.706 showing that the association between Dividend payout ratio and Corporate Shareholdings Structure used in the study is $71 \%$ which is positively, strongly and statistically significant. This implies that for any changes in Corporate Shareholdings Structure of listed Chemical and Paints Companies in Nigeria; their Dividend Payout ratio will be directly affected.

The cumulative R2 (0.499) which is the multiple coefficient of determination gives the proportion of the total variation in the endogenous variable explained by the exogenous variables jointly. Hence, it signifies $50 \%$ of the total variation in Dividend payout ratio of listed Chemical and Paints Companies in Nigeria is caused by their Managerial shareholdings, Institutional shareholdings, Block shareholdings and foreign shareholdings. This indicates that the model of the study is fit and the exogenous variables are properly selected, combined and used.

The Durbin Watson tests of first order auto-correlation which have a value of 1.295 indicates that errors are uncorrelated to each other indicating absence of serial correlation within the period of the study.

Managerial shareholdings and Dividend payout ratio

From the table above, Managerial Shareholdings has a t-value of -3.162 and a coefficient value of -0.580 which is significant at $1 \%$. This signifies that managerial shareholding has negative, strong and significant influence on the Dividend payout ratio of listed Chemical and Paints Companies in Nigeria. It therefore implies that for every $1 \%$ increase in the number of shares held by directors, the Dividend payout ratio of listed Chemical and Paints will decrease by $\mathrm{N} 0.58$

This provides an evidence of rejecting null hypothesis one of the study which states that managerial shareholdings has no significant influence on dividend payout ratio.

Institutional shareholdings and Dividend payout ratio

From the table above, Institutional shareholding has a t-value of 2.137 and a coefficient value of 0.295 which is significant at 5\%. This signifies that Institutional shareholdings have positive, strong and significant influence on the Dividend payout ratio of listed Chemical and Paints Companies in Nigeria. It therefore implies that for every $1 \%$ increase in the Proportion of shares held by Institutions in listed Chemical and Paints Companies in Nigeria, the Dividend payout ratio will increase by N0.30.

This provides an evidence of rejecting null hypothesis two of the study which states that institutional shareholdings has no significant effect on dividend payout ratio

\section{Block shareholdings and Dividend Payout ratio}

From the table above, Block shareholding has a t-value of -1.004 and a coefficient value of -0.185 which is insignificant. This signifies that Block shareholdings is negatively, weakly and insignificantly influencing the dividend payout ratio of listed Chemical and Paints Companies in Nigeria. It therefore implies that for every $1 \%$ increase in the number of shares held in block in listed Chemical and Paints Companies in Nigeria within the study period, the Dividend payout ratio have no any significant changes.

This provides an evidence of failing to reject null hypothesis three of the study which states that block shareholdings has no significant impact on dividend payout ratio.

Foreign shareholdings and Dividend payout ratio

From the table above, foreign shareholding has a t-value of 2.465 and a coefficient value of 0.756 which is significant at $5 \%$. This signifies that foreign shareholdings have positive, strong and significant influence on the Dividend payout ratio of listed Chemical and Paints Companies in Nigeria. It therefore implies that for every $1 \%$ increase in the Proportion of shares held by foreigners in listed Chemical and Paints Companies in Nigeria, the dividend payout ratio will increase by $\mathrm{N} 0.76$.

This provides an evidence of rejecting null hypothesis four of the study which states that foreign shareholdings has no significant effect on dividend payout ratio

\section{Conclusions}

It is concluded that corporate shareholdings proxies have influence on the dividend payout ratio of listed chemical and paints companies in Nigeria. It is recommended amongst others that the listed Chemical and Paints Companies should increase the number of shares allotted to institutional shareholders and foreign shareholders where investors are only interested in dividend payment as it may serve as a sure means of having increase in payment of dividend to shareholders. But where shareholders are only interested in capital gain rather than dividend payment, the shares held by management should be increased as this will discourage payment of high dividend in favour of capital gain. 


\section{References}

Amidu, M. (2007). How Does Dividend Policy Affect Performance of The Firm On Ghana Stock Exchange? Investment Management and Financial Innovations, 4(2), 103 -112.

Bhattacharya, S. (1979), Imperfect Information, Dividend Policy, and 'The Bird in the Hand Fallacy. Bell Journal of Economics, 10(1), 259-270. http://dx.doi.org/10.2307/3003330

Chen, Z. H., Cheung, Y., Stouraitis, A. \& Wong, A. (2005). Ownership Concentration, Firm Performance and dividend policy in hong-kong. Pac. Bas. Finance Journal, 13, 431-449. http://dx.doi.org/10.1016/j.pacfin.2004.12.001

Easterbrook, F. H. (1984). Two agency-cost explanations of dividends. American Economic Review, 74, 220-30.

Eckbo, B. E. \& Verma, S. (1994). Managerial shareownership, voting power, and cash dividend policy. Journal of Corporate Finance, 1, 33- 62. http://dx.doi.org/10.1016/0929-1199(94)90009-4

Esmailzadeh, A., Jalili, M. \& Zand, A. (2010). Effect of Corporate Governance on Earnings Quality in Tehran Stock Exchange. Journal of Management Accounting, 3(7), 79-91.

Fakhari, H. \& Yosofalitabar, N. (2010). The survey of relationship between dividend policy and corporate governance in listed companies in Tehran Stock Exchange. Accounting and Auditing Review, 62, 69-84.

Fama E. F., Babiak, W. (1968). Dividend analysis: an empirical analysis. J. Am. Stat. Assoc., 63, 1132-1161. http://dx.doi.org/10.1080/01621459.1968.10480917

Gordon, M. (1962). The savings, investment and valuation of a corporation. Review of Economics and Statistics, 3(6), 37-51. http://dx.doi.org/10.2307/1926621

Gugler, K. \& Burcin, Y. (2003). Corporate governance and dividend pay-out policy in Germany. European Economic Review, 47,731-758. http://dx.doi.org/10.1016/S0014-2921(02)00291-X

Jensen, G. R., Donald S., \& Thomas, S. Z. (1992). Simultaneous Determination of Insider Ownership, Debt and Dividend Policies. The Journal of Financial and Quantitative Analysis, 27, 247-263. http://dx.doi.org/10.2307/2331370

Jensen, M. (1986). Agency Costs of Free Cash Flow, Corporate Finance, and Takeovers. American Economic Review, $76,323-329$.

Kang, J. K., \& Stulz, R. M. (1997). Why is there a home bias? An analysis of foreign portfolio equity ownership in Japan. Journal of Financial Economics, 46(1), 3-28. http://dx.doi.org/10.1016/S0304-405X(97)00023-8

Kouki, M., \& Guizani, M. (2009). Ownership Structure and dividend policy: Evidence from the Tunisian Stock Market. European Journal of Scientific Research, 25(1), 42-53.

Mashayekh, S., \& Abdollahi, M. (2011). The survey of relationship between ownership concentration, firm performance, and dividend policy in listed companies in the Tehran Stock Exchange, Financial Accounting Research Journal, 4, 71-86.

Maury, C., Pajuste, A. (2002). Controlling Shareholders, Agency problems, and Dividend Policy in Finland. Working Paper, Stockholm School of Economics, 7.

Mehrani, M., \& Eskandar. (2011).Ownership structure and dividend policy: Evidence from Iran, African Journal of Business Management, 5(17), 7516-7525.

Miller, M. H. \& Modigliani, F. (1961). Dividend policy, growth and the valuation of shares, The Journal of Business of the University Chicago, 34(4), 433-43. http://dx.doi.org/10.1086/294442

Mitton T (2005). Corporate governance and dividend policy in emerging markets. Emerg. Mark. Rev., 5, 409- 426. http://dx.doi.org/10.1016/j.ememar.2004.05.003

Ramli, N. M. (2010). Ownership Structure and Dividend Policy: Evidence from Malaysian Companies. International Review of Business Research Papers, 6(1), 170-180.

Rozeff, M. S. (1982). Growth, beta and agency costs as determinants of dividend payout ratios, Journal of Financial Research, 5(3), 249-259. http://dx.doi.org/10.1111/j.1475-6803.1982.tb00299.x

Shehu, U. H. \&. Buba, M. M. (2011). Board Characteristics and Loan Portfolio in Nigerian Money Deposit Banks, Nigerian Journal of Accounting Research, 7(1), 109-123.

Short, H., Hao, Z., \& Kevin, K. (2002). The link between dividend policy and institutional ownership, Journal of Corporate Finance, 8, 105-22. http://dx.doi.org/10.1016/S0929-1199(01)00030-X

Waud, R. (1966). Small sample bias due to misspecification in the 'partial adjustment' and 'adapted 
expectations'models. J. Am. Stat. Assoc., 134-145. http://dx.doi.org/10.2307/2283204

Wen, Y., \& Jia, J. (2010). Institutional Ownership, Managerial Ownership and Dividend Policy in Bank Holding Companies. International Review of Accounting, Banking and Finance, 2(1), 8-21.

\section{Appendix: Population of the Study}

1. African Paints (Nigeria) Plc

2. Berger Paints Plc

3 Chemical and Allied Products Plc

4. DN Meyer Plc

5. IPWA Plc

6. Paints and Coatings Manufacturers Nigeria Plc

7. Portland Paints and Products Nigeria Plc

8. Premier Paints Plc

\section{$(c)$ EY}

This work is licensed under a Creative Commons Attribution 3.0 License. 